\title{
A gestatiós diabetes mellitus súlyossága befolyásolja a három évvel a szülést követően mért microvascularis diszfunkció mértékét, amely kapcsolatban állhat az emelkedett szisztémás oxidatív stresszel
}

\author{
Horváth Eszter Mária dr. ${ }^{1,2}$ - Mágenheim Rita dr. ${ }^{3}$ \\ Domján Beatrix Annamária dr. ${ }^{3}$ - Ferencz Viktória dr. ${ }^{3}$ \\ Tänczer Tímea dr. ${ }^{3}$. Szabó Eszter dr. ${ }^{5}$. Benkő Rita dr. ${ }^{1,2}$ \\ Szabó Csaba dr. ${ }^{6}$. Tabák Ádám dr. ${ }^{3,7^{*}}$. Somogyi Anikó dr. ${ }^{4^{*}}$ \\ Semmelweis Egyetem, Általános Orvostudományi Kar, ${ }^{1}$ Élettani Intézet, ${ }^{2}$ Klinikai Kísérleti \\ Kutató- és Humán Élettani Intézet, ${ }^{3}$ I. Belgyógyászati Klinika, ${ }^{4}$ II. Belgyógyászati Klinika, Budapest \\ ${ }^{5}$ Szent Imre Egyetemi Oktatókórház, Budapest \\ ${ }^{6}$ Department of Anesthesiology, University of Texas Medical Branch, Galveston, TX, USA \\ ${ }^{7}$ Research Department of Epidemiology and Public Health, University College London, London, Egyesült Királyság
}

Bevezetés: Gestatiós diabetes mellitusban emelkedett oxidatív-nitratív stressz és poli(ADP-ribóz)-polimeráz-aktiváció van jelen, amely szerepet játszhat a későbbi élet során tapasztalt magasabb cardiovascularis kockázat kialakulásában. Célkitüzés: A szerző́k azt vizsgálták, hogy 3 évvel a szülés után a megelőző gestatiós diabetes súlyossága befolyásoljae az anyák érrendszerének állapotát, valamint milyen összefüggés mutatható ki az érfunkció romlása és az oxidatívnitratív stressz és poli(ADP-ribóz)-polimeráz-aktiváció között. Módszer: Korábban súlyos (inzulinnal kezelt) vagy enyhe (diétával kezelt) gestatiós diabetesen átesett 40 nő nagyartériáinak funkcióját applanációs tonometriával, a mikrokeringést provokációs tesztek elvégzése során lézer-Doppler-módszerrel vizsgálták. A véralkotókban mérhetô oxidatív-nitratív stresszt és poli(ADP-ribóz)-polimeráz-aktivációt kolorimetrás, valamint immunhisztokémiai technikával határozták meg. Eredmények: Inzulinnal kezelt gestatiós diabetesben a mikrokeringés zavarát, valamint az oxidatív stressz emelkedését mutatták ki. Következtetések: Az eredmények alapján az előzetesen igazolt gestatiós diabetes súlyossága befolyásolja a kialakuló microvascularis diszfunkció mértékét, amelyet emelkedett oxidatív stressz kísér. A nitratív stressz és a poli(ADP-ribóz)-polimeráz-aktiváció összefüggést mutat egyes vascularis paraméterekkel, bár ezek mértékét a betegség súlyossága nem befolyásolja. Orv. Hetil., 2015, 156(47), 1932-1936.

Kulcsszavak: gestatiós diabetes mellitus, oxidatív stressz, utánkövetés, vascularis funkció

The severity of gestational diabetes mellitus affects microvascular dysfunction measured three years after pregnancy that may be related to increased oxidative stress

Introduction: Oxidative-nitrative stress and poly(ADP-ribose) polymerase activation observed in gestational diabetes may play role in the increased cardiovascular risk in later life. Aim: The present study aimed to examine the influence of the severity of previous gestational diabetes (insulin need) on vascular function three years after delivery. Furthermore, the authors investigated the relation of vascular function with oxidative-nitrative stress and poly(ADP-ribose) polymerase activation. Method: Macrovascular function was measured by applanation tonometry; microvascular reactivity was assessed by provocation tests during Laser-Doppler flowmetry in 40 women who had gestational diabetes

*Dr. Somogyi Anikó és Dr. Tabák Ádám egyenlő mértékben vettek részt a tanulmány elkészítésében. 
3 years before the study. Oxidative-nitrative stress and poly(ADP-ribose) polymerase activity in blood components were determined by colorimetry and immunohistochemistry. Results: Three years after insulin treated gestational diabetes impaired microvascular function and increased oxidative stress was observed compared to mild cases. Conclusions: The severity of previous gestational diabetes affects microvascular dysfunction that is accompanied by elevated oxidative stress. Nitrative stress and poly(ADP-ribose) polymerase activity correlates with certain vascular factors not related to the severity of the disease.

Keywords: gestational diabetes, oxidative stress, follow-up, vascular function

Horváth, E. M., Mágenbeim, R., Domján, B. A., Ferencz, V., Tänczer, T., Szabó, E., Benkó, R., Szabó, Cs., Tabák, Á., Somogyi, $A$. [The severity of gestational diabetes mellitus affects microvascular dysfunction measured three years after pregnancy that may be related to increased oxidative stress]. Orv. Hetil., 2015, 156(47), 1932-1936.

(Beérkezett: 2015. szeptember 13.; elfogadva: 2015. szeptember 26.)

\section{Rövidítések}

4-HNE = 4-hidroxinoneal; cAix = arteria carotis augmentációs index; cfPWV = carotis-femoralis pulzushullám-terjedési sebessége $; \mathrm{LOOH}=$ lipidhidroperoxid $; \mathrm{MDA}=$ malondialdehid $\mathrm{NT}=$ nitrotirozin $; \mathrm{PAR}=$ poli $($ ADP-ribóz $) ; \mathrm{PARP}=$ poli $(\mathrm{ADP}-$ ribóz)-polimeráz; $\mathrm{PF}$ = csúcsáramlás; $\mathrm{PU}$ = perfúziós egység; TBARS $=$ tiobarbiturát reaktív anyagok

A gestatiós diabetes mellitus (GDM) a terhességek átlagosan 2-6\%-át érinti, rövid és hosszú távú szövődményei az anyát és a magzatot egyaránt veszélyeztetik. Az anyai szövődmények között szerepel a nagyobb számú szülési komplikáció, illetve a magasabb metabolikus és cardiovascularis kockázat a későbbi élet során [1].

$\mathrm{Az}$ emelkedett oxigén- és nitrogéneredetű szabad gyökök termelése és a csökkent antioxidáns-kapacitás az oxidatív-nitratív stressz jellemzői. Az oxidatív stressz következményei a lipidperoxidok, mint az oxidált LDL és a malondialdehid (MDA). Az egyik legreaktívabb oxidáns molekula, a peroxinitrit, a szuperoxid és a nitrogén-monoxid spontán reakciójában alakul ki. A fehérjék tirozin oldalláncainak irreverzibilis nitrációja (nitrotirozin NT) a peroxinitrit és hasonló reaktív nitrogénvegyületek jellemző reakciója. A peroxinitrit és a hidroxilgyökök DNS-töréseket okozhatnak. A DNS egyszálú törései obligát aktivátorai a sejtmagban található poli(ADP-ribóz)polimeráz (PARP) enzimnek, amely szerepet játszik a DNS-javításban és a génexpresszió szabályozásában. Nikotinamid-adenin-dinukleotid ${ }^{+}\left(\mathrm{NAD}^{+}\right)$-igényes múködése miatt azonban túlaktiválódása a sejt energiaraktárainak kimerüléséhez, illetve a sejt nekrózisához vezethet [2]. Az oxidatív-nitratív stressz és a következményes PARP-aktiváció szerepe jól ismert a 2-es típusú diabetes és számos cardiovascularis betegség patogenezisében. Az emelkedett vércukorszint az oxidatív-nitratív stressz és PARP-aktiváció emelkedéséhez vezet, ami tovább gyorsítja a 2-es típusú diabetes és szövődményeinek kórfolyamatát. Mindezek a folyamatok részt vesznek az endotheldiszfunkció kialakulásában, gyulladásos folyamatok beindulásában és ily módon az érelmeszesedés kialakulá- sában. Állatkísérletes modellekben a PARP farmakológiai gátlása javítja a diabeteses endotheldiszfunkciót [3].

Ismert, hogy GDM-ben emelkedett oxidatív-nitratív stressz, PARP-aktiváció és csökkent antioxidáns-kapacitás figyelhető meg az anyai és magzati szövetekben, amely eltérés szerepet játszhat a betegség patogenezisében, illetve egyes szövődmények kialakulásában [4]. Már 1998-ban leírták, hogy emelkedett malondialdehidszint mérhető GDM-ben szenvedő anyáktól és újszülöttjeiktől származó vörösvérsejtekben [5]. Később a lipidperoxidáció egyéb markereinek emelkedését - például 4-hidroxinonenal (4-HNE), TBARS (tiobarbiturát reaktív anyagok) és LOOH (lipidhidroperoxid) - is kimutatták. A placenta szöveteiben is emelkedett oxidatív stresszt találtak; magasabb xantinoxidáz-expresszió, MDA- és 4-HNE-szintek jellemzik a GDM-es placentát [6]. Korábbi tanulmányainkban kimutattuk, hogy a cardiovascularis kockázat becslésére is használható microvascularis endothelfunkciós vizsgálat, a posztokkluvíz reaktív hyperaemia (PORH) teszt során, 3 évvel a szülést követően, a korábban GDM-es anyák reakciókészsége szignifikánsan elmarad az egészséges terhesekhez képest [7]. A korábban súlyos (inzulinnal kezelt) GDM-en átesett várandósokban szignifikánsan magasabb szisztémás oxidatív stressz mérhető a szövődménymentes várandósokhoz képest [8].

Jelen tanulmányunkban azt vizsgáltuk, hogy 3 évvel a szülés után a megelőző GDM súlyossága befolyásolja-e az anyák ereinek macro- és microvascularis funkcióit, valamint milyen összefüggés mutatható ki az érfunkció romlása és az esetlegesen jelen lévő oxidatív-nitratív stressz és PARP-aktiváció között.

\section{Módszer}

\section{Betegek}

A vizsgálatba 40 nőt vontunk be GDM-mel szövődött terhességüket követő harmadik évben. 30 beteg esetében a terhességi diabetes enyhe lefolyású, diétával kontrollálható volt (enyhe GDM), 10 esetben azonban inzu- 
linkezelés bevezetése volt indokolt (súlyos GDM). A vizsgált nók kiválasztása során a két csoportba tartozó anyákat kor, BMI és szüléseik száma alapján egyeztettük. A vizsgálatok 2009 januárja és 2009 júniusa között a Semmelweis Egyetem I. Sz. Belgyógyászati Klinikáján történtek, a Semmelweis Egyetem Regionális Etikai Bizottsága engedélyének megfelelően (124/2007). A résztvevőktől minden esetben írásos beleegyezést kértünk.

\section{Klinikai vizsgálatok}

A betegek magasságát és súlyát kalibrált stadiométeren mértük. A BMI-t testtömeg $(\mathrm{kg}) /$ testmagasság $(\mathrm{m})^{2}$ képlet alapján számoltuk. A vérnyomást Riva-Rocci szerint határoztuk meg. A követéses vizsgálat során a WHO-ajánlásoknak megfelelő orális glükóztoleranciatesztet (OGTT) végeztünk $75 \mathrm{~g}$ glükózzal, amelynek során mértük az éhgyomri és a 120 perces vércukor- és inzulinértékeket. Emellett az éhgyomorra vett vérmintában meghatároztuk a $\mathrm{HbA}_{\mathrm{lc}}$-szintet, a triglicerid, az összkoleszterin, a HDL-koleszterin, az LDL-koleszterin, valamint a C-reaktív protein (CRP) szintjét. A klinikai vérvizsgálatok a Semmelweis Egyetem Központi Laboratóriumában történtek. A HOMA2B (homeostasis model assessment inzulin szekréció), illetve HOMA2S (inzulinérzékenység) számításához a HOMA-kalkulátor 2-es verzióját használtuk (Diabetes Trial Units, University of Oxford, Oxford, Egyesült Királyság).

\section{Cardiovascularis vizsgálatok}

A nagyartériák merevségét egyrészt az arteria (a.) carotis vérnyomásgörbéjén meghatározható augmentációs indexszel (cAix), valamint az a. carotis és a. femoralis közötti érszakaszon mért pulzushullám-terjedési sebességgel (cfPWV) jellemeztük. A méréseket mindkét esetben applanációs tonometriával végeztük (PulsePen, DiaTecne, Milánó, Olaszország). A microvascularis funkció vizsgálata során a bőr áramlását lézer-Dopplermódszerrel mértük (Periflux, Perimed AB, Jarfalla, Svédország). A mérőfej a jobb alkaron helyezkedett el. A posztokkluzív reaktív hyperaemia (PORH-) teszt során a jobb felkarra helyezett vérnyomásmérő mandzsettát a szisztolés vérnyomást $20 \mathrm{Hgmm}$-rel meghaladó értékre fújtuk fel, ezzel elzárva az a. brachialis áramlását. Az okklúzió 5 percig tartott, majd az áramlást további 10 percig regisztráltuk. A PORH jellemzésére a következő paramétereket használtuk: (1) a felengedést követő csúcsáramlás, (2) maximális áramlás (csúcsáramlás - nyugalmi áramlás), (3) felengedéstől a maximális áramlásig eltelt idő (csúcsig tartó idő), valamint (4) PORH-index (csúcsáramlás 1 perces átlaga/felengedést követő áramlás 1 perces átlaga). Az értékeket perfúziós egységben (PU) adtuk meg. Az acetil-kolin indukálta mikrocirkulációs áramlásfokozódás mérése során az acetil-kolint iontoforetikus módszerrel juttattuk a bőrbe (PeriIont, Peri- med $\mathrm{AB})$. A nyugalmi áramlás regisztrálását követően két dózis acetil-kolint (1\%, Clinalfa AG, Svédország) juttattunk a bőrbe anódáram segítségével $(0,1 \mathrm{~mA} 30 \mathrm{~s}$-ig és $0,16 \mathrm{~mA} 30 \mathrm{~s}$-ig) 120 s eltéréssel. Az egyes dózisok során kialakult áramlásfokozódást a nyugalmi áramláshoz viszonyítottuk. A lokális melegítés hatására létrejövő keringésfokozódás mérése során a speciális melegíthető mérőfejet a lábhátra, az I. ujj tövénél rögzítettük. A nyugalmi áramlás regisztrálását követően (l perc) 1 percig 44 ${ }^{\circ} \mathrm{C}$-on melegítettük a bőr kis területét, majd a hyperaemiás csúcsérték és a nyugalmi áramlás arányát számítottuk $(\mathrm{PF} \%)$.

\section{Véralkotókban mérhetó oxidatí-nitratín stressz és PARP-aktiváció}

A meghatározások éhgyomorra vett vérmintákban történtek. A plazma összperoxidszintjét Oxystat kit (Biomedica, Bécs, Ausztria) felhasználásával mértük. A fehérjenitráció és a PARP-aktiváció mértékét izolált keringő mononukleáris sejtekben antinitrotirozin (NT) (Calbiochem, Temecula, CA, Amerikai Egyesült Államok; 1:80, overnight, $4^{\circ} \mathrm{C}$ ) és anti-poli(ADP)-ribóz (PAR) (Calbiochem; 1:1000, overnight, $\left.4{ }^{\circ} \mathrm{C}\right)$ antitesttel végzett immunhisztokémiai jelöléssel becsültük. A pozitív sejtterületek arányát az összes sejtterülethez képest számítógépes képanalizátor programmal (MBFImageJ) végeztük [4].

\section{Statisztikai módszerek}

Az adatokat normáleloszlás esetében átlag \pm SD formában mutatjuk be. Azokat a változókat, amelyek nem normáleloszlást mutatnak, logaritmizált formában elemeztük tovább, és medián (IQR) formában adjuk meg. A csoportok közötti különbséget kétmintás T-próbával vizsgáltuk. Az egyes változók közötti összefüggéseket Pearson szerint elemeztük.

\section{Eredmények}

\section{A betegek antropometriai és klinikai adatai}

A betegek átlagéletkora, szüléseik száma, BMI-je, valamint szisztolés és diasztolés vérnyomása nem különbözött szignifikánsan egymástól. A laboratóriumi mérések közül súlyos GDM-et követően magasabb $\mathrm{HbA}_{\mathrm{lc}_{\mathrm{c}}}$-szintet találtunk, míg a többi változó esetében nem volt szignifikáns különbség a két csoport között (1. táblázat).

\section{A súlyos GDM késöi hatásai egyes cardiovascularis paraméterekre}

A korábban súlyos, inzulinnal kezelt GDM-ben szenvedő nők esetében elsősorban a microvascularis keringés érintettsége mutatható ki. Az enyhe GDM-es csoporthoz képest a posztokkluzív hyperaemiateszt (PORH- 
1. táblázat | A betegek klinikai és antropometriai adatai

\begin{tabular}{lll}
\hline & GDM & Súlyos GDM \\
\hline $\mathrm{N}$ & 30 & 10 \\
Kor (év) & $35,0 \pm 4,0$ & $36,5 \pm 6,0$ \\
Szülések száma & $1,7 \pm 0,8$ & $1,9 \pm 0,7$ \\
BMI (kg/m²) & $25,2 \pm 3,9$ & $25,1 \pm 3,6$ \\
Szisztolés vérnyomás (Hgmm) & $124,2 \pm 13,0$ & $126,6 \pm 20,6$ \\
Diasztolés vérnyomás (Hgmm) & $82,9 \pm 8,0$ & $82,1 \pm 9,6$ \\
HbA 1 (\%) & $5,5 \pm 0,3$ & $5,7 \pm 0,3 *$ \\
Éhomi glükóz (mmol/1) & $5,4 \pm 0,5$ & $5,4 \pm 0,5$ \\
OGTT 120 min glükóz (mmol/1) & $6,5 \pm 1,5$ & $7,1 \pm 2,5$ \\
Éhomi inzulin (ng/ml) & $14,8 \pm 7,2$ & $11,8 \pm 7,7$ \\
OGTT 120 min inzulin (ng/ml) & $76,6 \pm 66,2$ & $61,2 \pm 39,6$ \\
HOMA2B & $107,1 \pm 37,0$ & $109,7 \pm 52,8$ \\
HOMA2S & $79,6 \pm 38,6$ & $94,9 \pm 63,0$ \\
Triglicerid (mmol/l) & $1,4 \pm 1,6$ & $1,8 \pm 1,5$ \\
Összkoleszterin (mmol/1) & $4,8 \pm 0,8$ & $5,1 \pm 1$ \\
HDL-koleszterin (mmol/1) & $1,6 \pm 0,4$ & $1,4 \pm 0,3$ \\
LDL-koleszterin (mmol/1) & $3,2 \pm 1,2$ & $3,3 \pm 0,8$ \\
CRP (mg/l) & $1,1(0,7 ; 1,9)$ & $2,1(1 ; 4,9)$ \\
\hline
\end{tabular}

A táblázatban szereplő adatok normáleloszlású változók esetében átlag ${ }_{ \pm} \mathrm{SD}$, nem normáleloszlást mutató változók esetében medián (IQR). * ${ }^{*}<0,05$ : kétmintás T-próba.

csúcs, PORH-maximum, PORH-maximum ideje), illetve a melegítéssel kiváltott lokális keringésfokozódás esetében találtunk szignifikánsan csökkent vascularis reakciókat. Ezzel szemben a nagyerek rigiditására jellemző paraméterek tekintetében nem találtunk szignifikáns különbséget (2. táblázat).

\section{A súlyos GDM hatásai a véralkotókban mérhetó oxidatip-nitratín stresszre és PARP-aktivációra}

A szisztémás oxidatív stresszre karakterisztikus plazmaösszperoxid-szint a korábban súlyos GDM-en átesett betegekben mintegy kétszerese az enyhe GDM-en átesettekhez képest. A szisztémás nitratív stresszt és PARP-aktivációt jellemző leukocyta-tirozin nitráció és fehérje-PARálódás tekintetében azonban nem találtunk szignifikáns különbséget a két vizsgálati csoport között (3. táblázat).

3. táblázat |Véralkotókban mérhető oxidatív-nitratív stressz és PARP-aktiváció

\begin{tabular}{lll}
\hline & Enyhe GDM & Súlyos GDM \\
\hline Plazmaösszperoxid $(\mathrm{mmol} / 1)$ & $601,7 \pm 180,0$ & $920,7 \pm 504,9^{*}$ \\
Leukocyta NT (area\%) & $14,8(7,4 ; 49,3)$ & $26,8(11,7 ; 55,1)$ \\
Leukocyta PAR (area\%) & $11,4(5,4 ; 22,0)$ & $12,3(4,6 ; 21,4)$ \\
\hline
\end{tabular}

A táblázatban szereplő adatok normáleloszlású változók esetében átlag $\pm \mathrm{SD}$, nem normáleloszlást mutató változók esetében medián $(\mathrm{IQR}) .{ }^{*} \mathrm{p}<0,05$ : kétmintás T-próba.
2. táblázat | Cardiovascularis mérések eredményei

\begin{tabular}{lll}
\hline & Enyhe GDM & Súlyos GDM \\
\hline cAix & $-0,4 \pm 12,5$ & $7,7 \pm 14,0$ \\
cfPWV $(\mathrm{m} / \mathrm{s})$ & $6,3 \pm 0,9$ & $6,6 \pm 0,8$ \\
Ach PF 1 (\%) & $655,7 \pm 608,5$ & $425,6 \pm 260,8$ \\
Ach PF 2 (\%) & $1036,1 \pm 576,1$ & $923,0 \pm 511,4$ \\
PORH-index & $3,5 \pm 0,9$ & $2,9 \pm 0,5$ \\
PORH-csúcs (PU) & $39,8(32,2 ; 55,4)$ & $34,7(30,8 ; 40,3)^{*}$ \\
PORH-maximum (PU) & $34,2(27,0 ; 48,1)$ & $28,1(21,0 ; 32,1)^{*}$ \\
PORH-csúcsig tartó idő $(\mathrm{s})$ & $4,0(2,3 ; 5,9)$ & $2,4(1,8 ; 2,4)^{*}$ \\
Melegítés PF (\%) & $2227,5 \pm 1090,1$ & $1003,1 \pm 333,9^{*}$ \\
\hline
\end{tabular}

A táblázatban szereplő adatok normáleloszlású változók esetében átlag ${ }_{ \pm} \mathrm{SD}$, nem normáleloszlást mutató változók esetében medián (IQR). ${ }^{*} \mathrm{p}<0,05$ : kétmintás T-próba.

\section{A véralkotókban mérhetô oxidativ-nitrativ stressz és PARP-aktiváció összefïggése a mért cardiovascularis paraméterekkel}

Amellett, hogy a súlyos GDM-et követő romló microvascularis teszt eredményeit emelkedett szisztémás oxidatív stressz kíséri, olyan paraméterek között is találtunk statisztikailag szignifikáns kapcsolatot, amelyeket a GDM súlyossága nem befolyásol. Így az augmentációs index (cAIX) nagysága pozitívan korrelál a leukocytákban mérhetô PARP-aktivációval (log Leukocita PAR). Az acetilkolin-iontoforézis során az első és a második acetil-kolindózis által kiváltott keringésfokozódás mértéke (Ach PF l és 2) negatív összefüggést mutat a szisztémás nitrozatív stresszel (log Leukocita NT) (4. táblázat).

\section{Megbeszélés}

A GDM-mel szövődött terhességet követően kialakuló macro- és microvascularis diszfunkciót számos klinikai vizsgálat igazolta. Kimutatták a nagyerek rugalmasságának csökkenését [9], az a. carotis intima-media vastagságának növekedését [10], valamint az endothelfüggő vasodilatatio csökkenését [11], bár egyes tanulmányok ennek ellentmondó eredményre jutottak [12, 13]. Több esetben a kialakuló vascularis diszfunkció hátterében magasabb testsúlyt, rosszabb cukor- és lipidháztartást, vala-

4. táblázat A véralkotókban mérhető oxidatív-nitratív stressz és PARP-aktiváció összefüggése a cardiovascularis paraméterekkel

\begin{tabular}{llccc}
\hline & & cAix & Ach PF 1 (\%) & Ach PF 2 (\%) \\
\hline $\log$ & $\mathrm{R}$ & & $-0,849$ & $-0,81$ \\
$($ Leukocyta NT [area\%]) & $\mathrm{p}$ & & 0,000 & 0,000 \\
\hline $\log$ & $\mathrm{R}$ & 0,412 & & \\
$($ Leukocyta PAR & $\mathrm{p}$ & 0,017 & & \\
{$[$ area\%]) } & & & & \\
\hline
\end{tabular}

R: Pearson-féle korrelációs koefficiens, p: szignifikanciaszint. 
mint szubklinikai gyulladást feltételeztek $[9,10,11]$. Néhány vizsgálatban azonban sikerült igazolni, hogy a megelőző GDM mindezektől a paraméterektől függetlenül is hozzájárul az erek múködésének zavarához [14, 15]. Jelen eredményeink alapján a gestatiós diabetesszel szövődött terhességet követő harmadik évben kimutatható romló microvascularis funkciót szignifikánsan befolyásolja a GDM súlyossága, amely hatás nem függ a testsúlytól, illetve a lipidháztartás zavarától. Mivel a korábban inzulinnal kezelt csoportban kismértékben, de szignifikánsan magasabb $\mathrm{HbA}_{1 \mathrm{c}}$-szintet mértünk, a glükózanyagcsere befolyása nem zárható ki a jelenség kialakulásában. A megelőző GDM súlyosságának hatását a késóbbi érfunkcióra korábban az a. carotis intima-media vastagságának mérésével vizsgálták, amelynek során igazolták is annak növekedését a korábban inzulinterápiában részesültek körében. A microvascularis funkcióval kapcsolatban azonban korábban ilyen jellegü vizsgálat nem történt. E két tanulmány alapján mind a nagy-, mind a kiserek funkciójának romlása gestatiós diabetest követően összefügg a betegség súlyosságával. A GDM súlyosságától függő microvascularis diszfunkcióval párhuzamosan vizsgálatunkban emelkedett szisztémás oxidatív stresszt is tapasztaltunk, amely - ismerve az oxidatív stressz jelentőségét az endotheldiszfunkció kialakulásában - jelentős szerepet játszhat a kiserek múködészavarának létrejöttében. Annak ellenére, hogy a keringő leukocytákban mérhető nitratív stressz, illetve PARP-aktiváció mértéke nem különbözött a két csoportban, kíváncsiak voltunk, hogy nagyságuk korrelációt mutat-e valamely általunk meghatározott cardiovascularis paraméterrel. Eredményeink alapján a nitratív stressz mértéke negatív kapcsolatban áll a microvascularis funkciót, ezen belül is az endotheldiszfunkciót jellemző acetil-kolin indukálta vasodilatatióval, amely mutató ugyancsak nem különbözött a két betegkategóriában. A jelenség hátterében a nitrogén-monoxidnak a peroxinitritképződés miatti biológiai elérhetőségcsökkenése állhat. A PARP-aktiváció ezzel szemben a nagyerek merevségét jellemző augmentációs indexszel mutatott pozitív korrelációt, ezzel is alátámasztva az enzimaktiváció szerepét az atherosclerosis patogenezisében.

Eredményeink alapján a három évvel a GDM-mel szövődött terhességet követően kialakuló microvascularis diszfunkció mértékét - amelyet emelkedett oxidatív stressz kísér - befolyásolja a megelőző GDM súlyossága. A szisztémás nitratív stressz és PARP-aktiváció ugyancsak összefüggést mutat egyes nagy- és kisérfunkciós paraméterrel, bár ezek mértékét a betegség súlyossága nem befolyásolja.

Anyagi támogatás: OTKA-K68575, OTKA-PD1 13022. Dr. Horváth Eszter Máriát a Bólyai János Kutatási Ösztöndíj támogatta.

Szerzői munkamegosztás: H. E. M.: Hipotézisek kidolgozása, oxidatívstressz-mérések lefolytatása, statisztikai elemzések, kézirat megszövegezése. M. R., T. Á.: Hipotézisek kidolgozása, klinikai mérések elvégzése, statisztikai elemzések, kézirat javítása. D. B. A., F. V., T. T., Sz. E.: Klinikai mérések elvégzése, kézirat javítása. B. R.: Oxidatívstressz-mérések lefolytatása, kézirat ellenőrzése. Sz. Cs.: Hipotézisek kidolgozása, oxidatív stresszmérések lektorálása,a kézirat ellenőrzése. S. A.: Hipotézisek kidolgozása, kézirat megszövegezése. A cikk végleges változatát valamennyi szerző elolvasta és jóváhagyta.

Érdekeltségek: A szerzőknek nincsenek érdekeltségeik.

\section{Irodalom}

[1] Kun, A., Tornóczky, J., Tabák, A. G.: The prevalence and predictors of gestational diabetes mellitus in Hungary. Horm. Metab. Res., 2011, 43(11), 788-793.

[2] Garcia Soriano, F., Virág, L., Jagtap, P., et al.: Diabetic endothelial dysfunction: the role of poly(ADP-ribose) polymerase activation. Nat. Med., 2001, 7(1), 108-113.

[3] Szabo, C.: Role of nitrosative stress in the pathogenesis of diabetic vascular dysfunction. Br. J. Pharmacol., 2009, 156(5), 713-727

[4] Horváth, E. M., Magenheim, R., Kugler, E., et al.: Nitrative stress and poly(ADP-ribose) polymerase activation in healthy and gestational diabetic pregnancies. Diabetologia, 2009, 52(9), 19351943.

[5] Kamath, U. G., Rao, G., Raghothama, C., Rai, L., et al.: Erythrocyte indicators of oxidative stress in gestational diabetes. Acta Paediatr., 1998, 87(6), 676-679.

[6] Lappas, M., Hiden, U., Desoye, G., et al.: The role of oxidative stress in the pathophysiology of gestational diabetes mellitus. Antioxid. Redox Signal., 2011, 15(12), 3061-3100.

[7] Tabák, Gy. Á., Járai, Z., Magenbeim, R., et al.: Postocclusive reactive hyperaemia 3 years after gestational diabetes mellitus. [A posztokkluzív reaktív hyperaemia vizsgálata lézer-doppleráramlásméréssel három évvel gestatiós diabetest követően.] Magy. Belorv. Arch., 2011, 64(6), 375-383. [Hungarian]

[8] Horvath, E. M., Benko, R., Magenheim, R., et al.: Oxidative stress may stay elevated after gestational diabetic and even healthy pregnancies. Diabetologia, 2010, 53(Suppl. 1), S556.

[9] Lekva, T., Bollerslev, J., Norwitz, E. R., et al.: Aortic stiffness and cardiovascular risk in women with previous gestational diabetes mellitus. PLoS ONE, 2015, 10(8), e0136892.

[10] Bo, S., Valpreda, S., Menato, G., et al.: Should we consider gestational diabetes a vascular risk factor? Atherosclerosis, 2007, 194(2), e72-e79.

[11] Anastasiou, E., Lekakis, J. P., Alevizaki, M., et al.: Impaired endothelium-dependent vasodilatation in women with previous gestational diabetes. Diabetes Care, 1998, 21(12), 2111-2115.

[12] Ku, Y. H., Choi, S. H., Lim, S., et al.: Carotid intimal-medial thickness is not increased in women with previous gestational diabetes mellitus. Diabetes Metab. J., 2011, 35(5), 497-503.

[13] Banerjee, M., Anderson, S. G., Malik, R. A., et al.: Small artery function 2 years postpartum in women with altered glycaemic distributions in their preceding pregnancy. Clin. Sci. (Lond.), 2012, 122(2), 53-61.

[14] Freire, C. M., Barbosa, F. B., de Almeida, M. C., et al.: Previous gestational diabetes is independently associated with increased carotid intima-media thickness, similarly to metabolic syndrome - a case control study. Cardiovasc. Diabetol., 2012, 11, 59.

[15] Fakhrzadeh, H., Alatab, S., Sharifi, F., et al.: Carotid intima media thickness, brachial flow mediated dilatation and previous history of gestational diabetes mellitus. J. Obstet. Gynaecol. Res., 2012, 38(8), 1057-1063.

(Horváth Eszter Mária dr., Budapest, Tűzoltó u. 37-47., 1094 e-mail: horvath.eszter@med.semmelweis-univ.hu) 